\title{
O MODERNO E O MÍTICO NA PERCEPÇÃO POPULAR SOBRE AS MONTANHAS: O CASO DA SERRA DO MAR PARANAENSE ${ }^{1}$
}

\begin{abstract}
Altair Gomes Brito ${ }^{2}$
Historicamente, as montanhas têm representado um desafio ao domínio e ao entendimento humanos: são elementos da natureza permanentemente presentes no mundo dos homens (TUAN, 1980, p.81). Distinguindo-se como formas naturais marcantes na paisagem, as montanhas geram interpretações carregadas de simbolismo e mitos. Muitas destas interpretações se revelam antagônicas: elas são relacionadas ao belo e ao feio, ao sublime e ao perigoso, à admiração e ao temor, ao sagrado - nela estaríamos "mais perto de Deus" - e ao maldito. Neste estudo nos propomos investigar quais destes mitos e associações ainda se fazem presentes nos dias atuais, e porquê perduram ao longo dos séculos. Alguns sobrevivem mesclados com sentimentos recentes, derivados de elementos modernos: atividades turísticas e esportivas em ambientes montanhosos, criação de unidades de conservação, cobertura nos meios de comunicação sobre conquistas e tragédias envolvendo escaladores. Que papel têm no imaginário popular estas novas influências? As montanhas também resistem aos processos transformadores do homem: o avanço da urbanização encontra no relevo acidentado uma barreira muitas vezes intransponível fisicamente. Isoladas ou agrupadas em serras, as montanhas desviam e limitam regionalmente a expansão urbana. Com o passar do tempo, as áreas montanhosas são rodeadas pelo solo ocupado, num cerco ressaltado pelas ações de proteção à natureza relativamente intocada que ali se refugia. Assim, a relação entre homens e montanhas guarda, além de reflexões importantes, estreitas ligações com a própria relação homem-natureza estabelecida pela sociedade contemporânea. A análise conduz a uma abordagem socio-ambiental diferenciada, que buscará no olhar sobre a Serra do Mar paranaense elementos espaciais e empíricos essenciais.
\end{abstract}

PALAVRAS-CHAVE: montanhas; natureza; simbolismo.

\footnotetext{
${ }^{1}$ Orientadora: Profa.dra. Salete Kozel

${ }^{2}$ Mestrando em Geografia (UFPR) - e-mail: agbqb@yahoo.com.br
} 